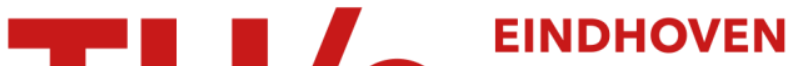 UNIVERSITY OF TECHNOLOGY
}

\section{Crystal structure and conductivity of the organometallic linear chain system (Et4N)[Ni(dmit)2] and related compounds}

\section{Citation for published version (APA):}

Kramer, G. J., Groeneveld, L. R., Joppe, J. L., Brom, H. B., Jongh, de, L. J., \& Reedijk, J. A. (1987). Crystal structure and conductivity of the organometallic linear chain system (Et4N)[Ni(dmit)2] and related compounds. Synthetic Metals, 19(1-3), 745-750. https://doi.org/10.1016/0379-6779(87)90446-2

DOI:

10.1016/0379-6779(87)90446-2

Document status and date:

Published: 01/01/1987

\section{Document Version:}

Publisher's PDF, also known as Version of Record (includes final page, issue and volume numbers)

\section{Please check the document version of this publication:}

- A submitted manuscript is the version of the article upon submission and before peer-review. There can be important differences between the submitted version and the official published version of record. People interested in the research are advised to contact the author for the final version of the publication, or visit the $\mathrm{DOI}$ to the publisher's website.

- The final author version and the galley proof are versions of the publication after peer review.

- The final published version features the final layout of the paper including the volume, issue and page numbers.

Link to publication

\section{General rights}

Copyright and moral rights for the publications made accessible in the public portal are retained by the authors and/or other copyright owners and it is a condition of accessing publications that users recognise and abide by the legal requirements associated with these rights.

- Users may download and print one copy of any publication from the public portal for the purpose of private study or research.

- You may not further distribute the material or use it for any profit-making activity or commercial gain

- You may freely distribute the URL identifying the publication in the public portal.

If the publication is distributed under the terms of Article 25fa of the Dutch Copyright Act, indicated by the "Taverne" license above, please follow below link for the End User Agreement:

www.tue.nl/taverne

Take down policy

If you believe that this document breaches copyright please contact us at:

openaccess@tue.nl

providing details and we will investigate your claim. 
GRYSTAL STRUCTURE AND CONDUCTIVITY OF THE ORGANOMETALLIC LINEAR CHAIN SYSTEM $\left(\mathrm{Et}_{4}{ }_{4}{ }^{\mathrm{N}}\right)\left[\mathrm{N} 1(\mathrm{DMIT})_{2}\right]$ AND RELATED COMPOUNDS

G.J. KRAMER*, L.R. GROENEVELD**, J.L. JOPPE*, H.B. BROM*, L.J. DE JONGH* AND J. REEDIJK ${ }^{\star \star}$

* Kamerlingh Onnes Laboratory, State University of Leiden, Postbus 9506, 2300 RA Leiden (The Netherlands)

** Gorlaeus Laboratory, State University of Leiden, Postbus 9502, 2300 RA Leiden (The Netherlands)

\section{ABSTRACT}

The crystal structure and conductivity of single crystals of the linear chain system $\left(\mathrm{Et}_{4} \mathrm{~N}\right)\left[\mathrm{Ni}(\mathrm{dmI})_{2}\right]$ and a $\mathrm{Pd}$ analogue are presented. It appears that the structure 1s highly one-dimensional and perfectly regular. Nevertheless we find the temperature dependence of the resistivity to be of the form lno $\propto-\left(T_{0} / T\right)^{\frac{1}{2}}$, which is typical for 1-D disordered systems. A tentative explanation is given based on the extreme anisotropy of the compounds.

\section{INTRODUCTION}

Transition metals coordinated by the organic ligand isotrithione-dithiolato (dmit), provide a sultable acceptor molecule, which can be made to form highly anisotropic (low-dimensional) metals or semiconductors. In the literature examples of these systems are found exhibiting both 1- and 2-dimensional electronic behaviour $[1,2]$. In this contribution we will focus on two new examples of the series $\left(R_{4} N\right)\left[M(d m i t)_{2}\right]$, specifically $\left(E t_{4} N\right)\left[N 1(d m i t)_{2}\right]$ and $\left(E t_{4} N\right)_{0.5}$ $\left[\operatorname{Pd}(\mathrm{dml} t)_{2}\right]$. Both compounds show the same anomalous temperature dependence of the conductivity, which will be discussed in relation to the crystal structure.

THE SYNTHESIS AND COMPLEX FORMATION OF TETRAALKYLAMMONIUM BIS(ISOTRITHIONETHIOLATO) METAL CHELATES

The dianionic salts, $\left(\mathrm{NR}_{4}\right)_{2}\left[\mathrm{M}(\mathrm{dml} t)_{2}\right]$, with $\mathrm{R}=\mathrm{CH}_{3}, \mathrm{C}_{2} \mathrm{H}_{5}, \mathrm{C}_{3} \mathrm{H}_{7}$ or $\mathrm{C}_{4} \mathrm{H}_{9}$, have been prepared following a synthet1c method described in the literature $[1,3]$. Reaction of sodium and potassium with $\mathrm{Cs}_{2}$ yields the dmit ${ }^{2-}$ anion which is 
stabilized as the ztnc complex. Further reaction with benzoylchloride and sodium methoxide regenerates the dmit ${ }^{2-}$ ligand and is followed by the addition of the appropriate metal salt.

The $\left(R_{4} N\right)_{1}\left[M(d m i t)_{2}\right]$ coordination compounds have been prepared following two different routes: (i) oxidation of $\left(\mathrm{R}_{4} \mathrm{~N}\right)_{2}\left[\mathrm{M}(\mathrm{dmit})_{2}\right]$ by lodine ( $\left.\mathrm{I}_{2}\right)$; (ii) autooxidation of $\left(R_{4} N\right)_{2}\left[M(d m i t)_{2}\right]$ as described by Steimecke and co-workers [3].

The compounds were identified by infrared spectra (position of the $\mathrm{C}=\mathrm{C}$ vibration) [3], chemical analysis and EPR spectra. The compound $\left[\left(\mathrm{C}_{2} \mathrm{H}_{5}\right)_{4} \mathrm{~N}\right]_{0.5}$ $\left[\operatorname{Pd}(\mathrm{dmit})_{2}\right]$ was synthesized according to the second method with an excess of acetic acid.

THE CRYSTAL STRUCTURE OF TETRAETHYLAMMONIUM BIS(ISOTRITHIONE-DITHIOLATO) NICKELATE (III)

The crystal structure of $\left(\mathrm{Et}_{4} \mathrm{~N}\right){ }_{1} \mathrm{Ni}(\mathrm{dmit})_{2}$ was determined in order to help to interpret the conduction measurements. It should provide some information about the stacking of the $\mathrm{Ni}(\mathrm{dmit}) \overline{2}$-ions in this compound.

The $\mathrm{Ni}$ (III) compound crystallizes in space group $\mathrm{P} 2 \mathrm{f} / \mathrm{n}$ with parameters $a=7.333(1) \AA, b=25.743(3) \AA, c=12.798(4) \AA, \beta=104.95(2)^{\circ}, Z=4$ and $M W=581.6$. The structure was solved from the Patterson function followed by the use of the program AUTOFOUR [4] and least-squares refinement. Resulting final $R\left(R_{W}\right)$ values are $4.49(5.36)$.

The structure contalns quasi-planar $\left[\mathrm{N} 1(\mathrm{dmit})_{2}\right]$ molecules which are stacked along the a-axis. The planes containing N1,S1-S5, C1-C3 and Ni,s7-S10, C5-C6, respectively, have an inclination of $7.2^{\circ}$. The average value of the $\mathrm{Ni-S}$ bond distances is $2.157(4) \AA$. Short intermolecular contacts between the $\left[\mathrm{N} i(\mathrm{dmit})_{2}\right.$ ions within the chain are expected to give a considerable overlap of the valence orbitals and could therefore give rise to the observed conductivity (table 1; Figures 1 and 2).

TABLE 1

Some relevant distances within the chain

$\begin{array}{lll}\mathrm{Ni}(1)-\mathrm{N} 1(2) & 4.163 & \\ \mathrm{~N} 1(1)-\mathrm{Ni}(3) & 4.243 & \text { symmetry operations } \\ \mathrm{S} 8(1)-\mathrm{S} 4(2) & 3.660 & \text { (1) } \mathrm{x}, \mathrm{y}, \mathrm{z} \\ \mathrm{N} 1(1)-\mathrm{S} 2(3) & 3.506 & \text { (2) } 1-\mathrm{x},-\mathrm{y}, 1-\mathrm{z} \\ \mathrm{S} 5(1)-\mathrm{S} 8(3) & 3.711 & \text { (3) }-\mathrm{x},-\mathrm{y}, 1-\mathrm{z}\end{array}$




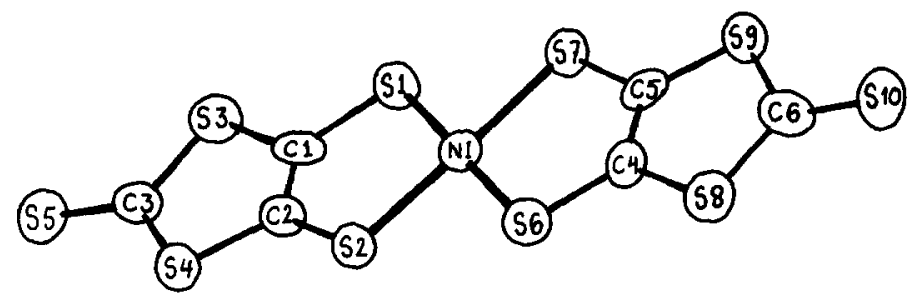

Fig. 1. The $\left[\mathrm{N} 1(\mathrm{III})(\mathrm{dmit})_{2}\right]-$ ion with atomic numbering.

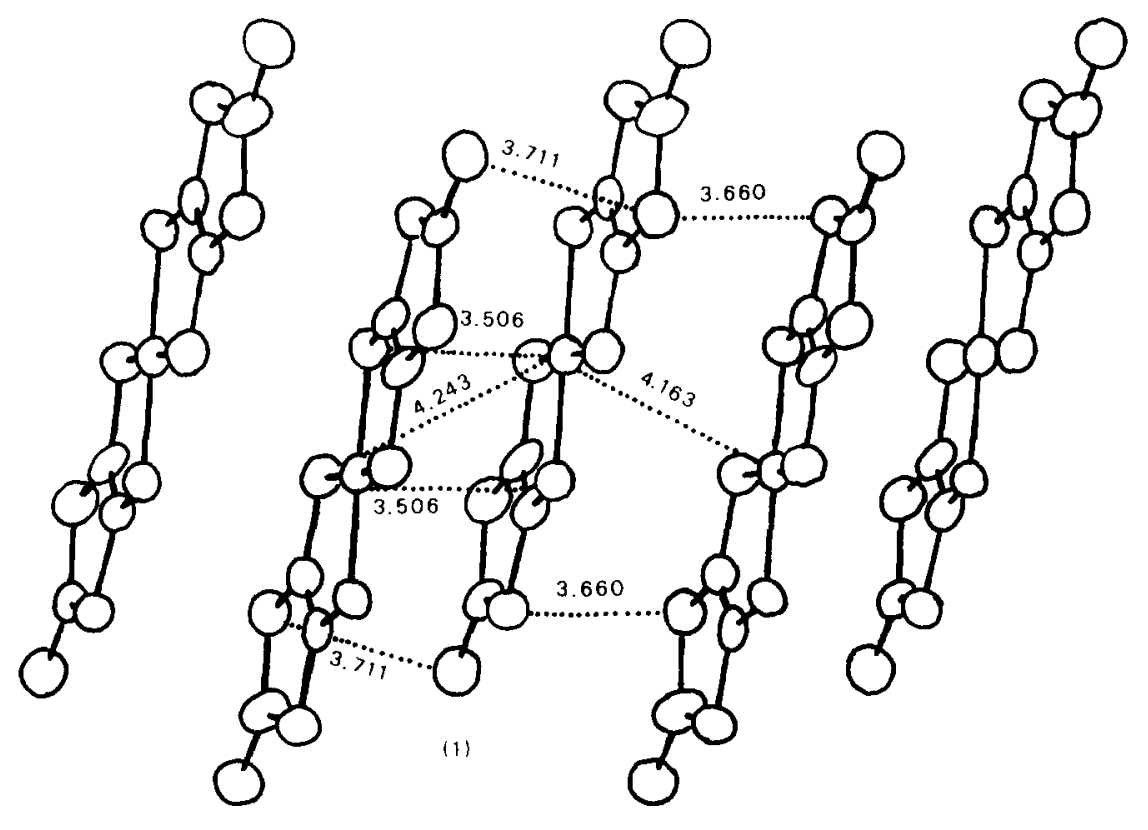

(3)

(2)

F1g. 2. Stacking of the $\left[\mathrm{N} 1(\mathrm{III})(\mathrm{dmit})_{2}\right]-1$ ons along the a-axis.

CONDUCTIVITY AND DISCUSSION

The conductivity of single crystals of $\left(\mathrm{Et}_{4} \mathrm{~N}\right)\left[\mathrm{Ni}(\mathrm{dmit})_{2}\right]$ and $\left(\mathrm{Et}_{4} \mathrm{~N}\right)_{0.5}$ $\left[\operatorname{Pd}(\operatorname{dmi} t)_{2}\right]$ was measured along the stacking axis. A two-probe method was employed and electrical contacts were painted on the sample with silver paint. The same method has been employed by others on a similar type of compound [2]. If the conductivity is interpreted in terms of an activated process, the room temperature activation energles are $0.25 \mathrm{eV}$ for the nickel compound and $0.05 \mathrm{eV}$ 
for the palladium compound. However the temperature dependence of the conductivity differs markedly from the usual semiconductor behaviour. F1g. 3 shows the results of these measurements plotted against $\mathrm{T}^{-\frac{1}{2}}$. One observes that the $\ln (\sigma) \propto \mathrm{T}^{-\frac{1}{2}}$ law holds over seven decades (!) in the conductivity for the nickel compound and over one decade of temperature for the palladium compound.

Such behaviour is often found in one-dimensional compounds, as was first reallzed by Bloch, Weissman and Varma in 1972 [5], who attributed it to a potentlal disorder induced on the conducting chain by randomness in the donor system. This randomness causes a localization of the electronic states, which

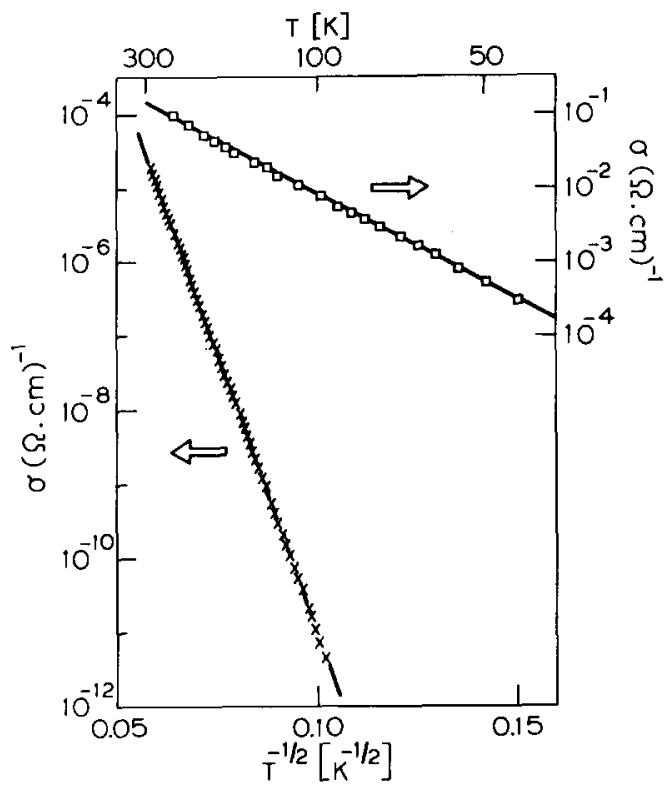

F1g. 3. Conductivity along the stacking axis of $\left(\mathrm{Et}_{4} \mathrm{~N}\right)\left[\mathrm{N1}(\mathrm{dmit})_{2}\right]$ (crosses) and $\left(\mathrm{Et}_{4} \mathrm{~N}\right)_{0.5}\left[\mathrm{Pd}(\mathrm{dmIt})_{2}\right]$ (squares) versus $\mathrm{T}^{-\frac{1}{2}}$.

In turn would explain the $\mathrm{T}^{-\frac{1}{2}}$ law for the conductivity, which is the 1-D prediction of a general formula for tunneling between localized states derived by Mott [6]. This behaviour has for instance been found in other coordination compounds like KCP [5]. In that case bromlum ions occupy the available sites randomly [7], thereby providing a logical source of disorder. The same $\mathrm{T}^{-\frac{1}{2}}$ law has recently been derived by Azbel on the basis of other arguments [8]. 
In $\left(\mathrm{Et}_{4} \mathrm{~N}\right)\left[\mathrm{NI}(\mathrm{dmIt})_{2}\right]$ however, the room temperature $\mathrm{X}$-ray study and crystal structure indicate that both donors and acceptors form a regular array without any static disorder. Therefore, the application of the above theories seems far off. On the other hand, In one dimension an arbitrary amount of disorder a1ready causes electron localization. Consequently, the higher the electrical anisotropy, the less disorder 18 needed to create electron localization. It appears that in $\left(\mathrm{Et}_{4} \mathrm{~N}\right)\left[\mathrm{N1}(\mathrm{dmi} t)_{2}\right]$ the stacks are extremely well separated. The smallest Interchain $\mathrm{S}-\mathrm{S}$ distance is of the order of $3.9 \mathrm{~A}$, much larger than the corresponding Van der Waals radius and much larger than those found in analogous compounds $[1,2]$. Furthermore, in preliminary measurements we find that $\sigma_{h}: \sigma_{\perp}$ exceeds 100. Therefore, one might expect that a degree of disorder which is too small to manifest itself in $X$-ray analysis is still capable of producing a disordered electron gas. As possible sources for disorder one may think of lattice defects, chemical impurities, or maybe dynamical disorder produced by thermal vibrations of the $\mathrm{Ni}(\mathrm{dmit})_{2}$ lons resulting in randomly disordered transfer Integrals. It would seem that the same arguments would hold for the palladium compound, for which the crystal structure is not known at present. A very high degree of anisotropy might also explain the low room temperature conductivity of the $\mathrm{Ni}$ (III) compound $4 \times 10^{-5}(\Omega \mathrm{cm})^{-1}$ with respect to the analogous but less anisotropic $\left(\mathrm{Et}_{4} \mathrm{~N}\right)_{0.5}\left[\mathrm{NI}(\mathrm{dmit})_{2}\right]\left(4 \times 10^{-2}(\Omega \mathrm{cm})^{-1}\right)$, for which the intrachain spacing is very much the same. On the other hand, the large difference in conductivity would also be due to silghtly different molecular stacking along the chain axes in both compounds.

Apart from the above considerations, which rely on the 1-dimensional nature of the compounds, we remark that the same $\ln \sigma \propto-\left(\mathrm{T}_{0} / \mathrm{T}\right)^{\frac{1}{2}}$ law has also been observed in other, widely different physical systems. In granular metal systems (cermets) for instance, many examples have been reported [9]. Quite recently, the same conductivity law was also found for a metal cluster compound [10]. In that case there is no distribution of particle sizes, which was thought to be cruclal in the cermet-case. This example, together with the 1-d system discussed in this paper provides us with two examples which, in spite of the lack of apparent disorder, show disorder-1ike behaviour. Th1s provides a challenging problem in the theory of order/disorder phenomena.

\section{REFERENCES}

1 L. Valade, J.P. Legros, M. Bousseau, P. Cassoux, M. Garbauskas and L.V. Interrante, J. Chem. Soc., Da1ton Trans., (1985) 783.

2 R. Kato, T. Mor1, A. Kobayash1, Y. Sasak1 and H. Kobayash1, Chem. Letters (1984) 1. 
3 G. Steimecke, H.J. Sieler, R. K1rmse and E. Hoyer, Phosphorus and Sulfur, 7 (1979) 49.

4 A.J. Kinneging and R.A.G. de Graaff, J. Appl. Cryst., 17 (1984) 364.

5 A.N. Bloch, R.B. Welsman and C.M. Varma, Phys. Rev. Lett., 28 (1972) 753.

6 N.F. Mott, Ph11. Mag., 19 (1969) 835.

7 H.R. Zeller, in H.J. Keller (ed.), Low-Dimensional Cooperative Phenomena, Plenum, New York, 1975.

8 M.Y. Azbel and D.P. DiVincenzo, Phys. Rev., B30 (1984) 6877.

9 See e.g. B. Abeles, Ping Sheng, M.D. Coutts and Y. Arle, Adv. Phys., 24 (1981) 407 .

10 M.P.J. van Staveren, H.B. Brom, L.J. de Jongh and G. Schmidt, to be published 